Proc. Estonian Acad. Sci. Geol., 2002, 51, 2, 121-132

\title{
Joint systems in Devonian sandstones in the Kiidjärve-Taevaskoda area, southeastern Estonia
}

\author{
Enn Pirrus $^{\mathrm{a}}$, Anne Kleesment ${ }^{\mathrm{b}}$, and Margus Sööt ${ }^{\mathrm{a}}$ \\ a Mining Institute of Tallinn Technical University, Kopli 82, 10412 Tallinn, Estonia; \\ pirrus@staff.ttu.ee \\ b Institute of Geology, Tallinn Technical University, Estonia pst. 7, 10143 Tallinn, Estonia; \\ kleesmen@gi.ee
}

Received 20 April 2001, in revised form 16 July 2001

\begin{abstract}
Data on the jointing of sandstone outcrops located in the area from Kiidjärve to Taevaskoda along the Ahja River are presented. Joints can usually be followed along the outcrop walls up to $15-20 \mathrm{~m}$ in the horizontal direction. In general, due to the stratification of the sandstone complex the vertical extent of joints is considerably smaller $-1.5-3 \mathrm{~m}$. Along with the dominating vertical joints, a number of dipping (35\%) joints are observed, having usually a dip between $60^{\circ}$ and $70^{\circ}$. The majority of joints belong to a system made up of two sets with azimuth bearings of strikes $287^{\circ}$ and $006^{\circ}$. The spacing of joints along the outcrops is variable, the average distance between them being 15-20 m. The cave structures of suffosional origin are formed mainly at the intersections of tilted and vertical joints. Because of the limited vertical extent of joints, most caves have a low arch-shaped cross section. Similar morphology of the caves is mostly due to the horizontally enlarging flow channel in the basal part of a joint. As a result the roof of the forming cave may collapse and give it a flat arch-shaped morphology. The research carried out in the Kiidjärve-Taevaskoda area gives a reliable basis for similar studies in other regions of Estonia.
\end{abstract}

Key words: jointing, caves, sandstone, Devonian, Estonia.

\section{INTRODUCTION}

Jointing of the Devonian bedrock is widespread in South Estonia, occurring mainly in fine-grained sandstones. Thus far this phenomenon has been very little studied, but it plays an important role in the understanding of the geological processes taking place within the sandstone. The connection between the orientation of joints and the river valleys has been pointed out by Miidel (1966, 1982). Joints support the formation of suffosional caves in bedrocks and surface 
whirlpools in lakes and rivers (Heinsalu 1987; Heinsalu et al. 1992). Concerning the groundwater circulation, the role of joints has been underestimated. Attention has been focused mainly on the porosity of the bedrock. However, large spring discharge areas are rarely formed solely by groundwater flow in the Devonian bedrock. Far more frequent are water-rich springs running off from joints on the valley slopes and recurring at certain intervals together with artesian water flows. Furthermore, horizontal variations in the colour of sandstone from grey to white are not observed in the area around the springs, where the rocks retain a yellowish or reddish shade. This is also the case in the immediate vicinity of joints. We could not find any evidence of the reduction process in the rock pores. At least it was not observed in the discharge zone of groundwater on the slopes, but presumably does not occur also in the deeper layers of the bedrock.

For the above reasons the jointing of sandstones deserves more attention. The very first results of a pilot study of joints over the Devonian outcrop area in Estonia (Kleesment \& Pirrus 2000) inspired continuation of the investigations in a more systematic way. The Devonian outcrops are generally small and scattered between numerous river valleys, which makes the study of the Devonian sequence very difficult. Exceptionally, some sections along the ancient river valleys like Ahja, Võhandu, and Piusa, where erosion has deeply cut into Devonian rocks, but also some cliff walls on the western and eastern shores of Lake Peipsi and Lake Võrtsjärv, respectively, provide good opportunities for joint research. Especially favourable for this purpose is the area between Kiidjärve and Suur Taevaskoda on the Ahja River, where 20 rather large outcrops occur within about $6 \mathrm{~km}$ (Fig. 1). Initial research of joints was performed in this area during the summer of 2000.

\section{MATERIAL AND METHODS}

In the above-mentioned stretch of the Ahja valley, rather homogeneous finegrained yellowish and pinkish sandstones of the Burtnieki Formation are exposed (Kleesment \& Mark-Kurik 1997). The sandstone contains rare lens-shaped clayey and, in some cases, conglomeratic interlayers. The conglomerate consists of small clay pebbles in a fine-grained matrix. In general, the entire complex consists of cross-bedded sandstone sets of variable thickness and declivity of foresets. Concerning the grain size distribution, the whole succession is relatively homogeneous, which makes it very suitable for measurement of joints and for interpretation of the stress field causing them.

The total length of all 20 outcrops is $1460 \mathrm{~m}$. All visible fractures were registered. When possible, their strike and dip, also their vertical and horizontal extent were measured. The character of the joint surfaces and their connections with caves were examined. The collected field data were processed statistically and presented graphically. The occurrence frequency of differently dipping joints was calculated, and the rose and vector diagrams of joint orientations were compiled. 


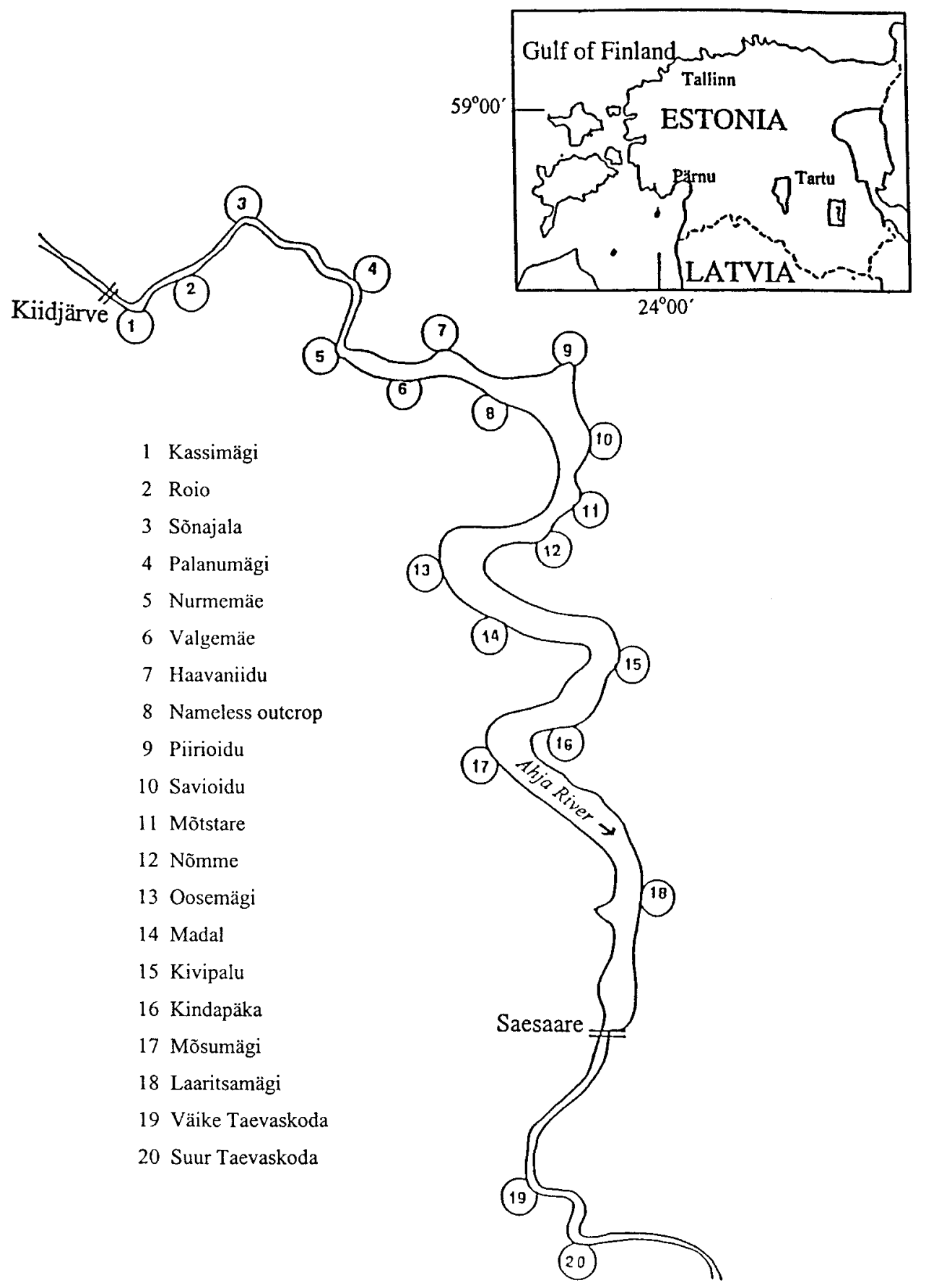

Fig. 1. Sketch-map of the research area and investigated outcrops on the Ahja River. 


\section{RESULTS \\ Spacing of joints}

In total, 119 joints were recorded in the exposed sandstone walls. Statistically, the mean distance between the visible joints is $11 \mathrm{~m}$. That is a slightly higher density than in the underlying sandstones of the Aruküla Formation, measured earlier at the Kallaste Bank and Tartu Cemetery (Kleesment \& Pirrus 2000). Still, distinct irregularity in the joint spacing in the limits of the research area must be kept in mind (Table 1). A few outcrops extend horizontally up to $100 \mathrm{~m}$ without any joints and cross the entire sandstone wall (Savioidu), but in some places the distance between joints varies from 1.5 to $4 \mathrm{~m}$ (Oosemägi, Kivipalu, Suur Taevaskoda, and Piirioidu). In six outcrops (Nõmme, Oosemägi, Madal, Kivipalu, Suur Taevaskoda, and Kindapäka) joint zones were detected, consisting of 3-5 parallel joints spacing $10-30 \mathrm{~cm}$ apart. Every joint zone probably makes up a quasicontinuous fracture and can be treated simply as one joint. If this is the case, the total number of measured joints is smaller and the estimated average spacing of joints is slightly higher $-15-20 \mathrm{~m}$. This is probably

Table 1. Measurements of investigated outcrops and joints

\begin{tabular}{|c|c|c|c|c|c|c|c|c|}
\hline \multicolumn{3}{|c|}{ Outcrop } & \multicolumn{3}{|c|}{ Vertical joint } & \multicolumn{3}{|c|}{ Dipping joint } \\
\hline Name & \begin{tabular}{|c|}
$\begin{array}{c}\text { Length, } \\
\mathrm{m}\end{array}$ \\
\end{tabular} & $\begin{array}{c}\text { Height, } \\
\mathrm{m}\end{array}$ & $\begin{array}{l}\text { Number } \\
\text { of joints }\end{array}$ & \begin{tabular}{|c|} 
Horizontal \\
extent, $\mathrm{m}$
\end{tabular} & $\begin{array}{c}\text { Vertical } \\
\text { extent, } \mathrm{m}\end{array}$ & $\begin{array}{l}\text { Number } \\
\text { of joints }\end{array}$ & $\begin{array}{c}\text { Vertical } \\
\text { extent, } \mathrm{m}\end{array}$ & $\begin{array}{l}\text { Caves, } \\
\text { gullies }\end{array}$ \\
\hline Kassimägi & 15 & 4 & 1 & 5 & & & & \\
\hline Roio & 30 & 5 & 1 & 25 & 5 & 1 & 5 & \\
\hline Sõnajala & 40 & 5 & 5 & 15 & $1-4$ & & & \\
\hline Palanumägi & 100 & 8 & 7 & $5-10$ & $1-3$ & 2 & 2 & 2 \\
\hline Nurmemäe & 15 & 2 & & & & & & \\
\hline Valgemäe & 60 & 5 & 1 & 10 & 2 & & & \\
\hline Haavaniidu & 30 & 3 & & & & & & \\
\hline Nameless & 15 & 1.5 & 1 & 3 & & & & \\
\hline Piirioidu & 100 & 10 & 6 & 15 & $2-3$ & 1 & 3 & 4 \\
\hline Savioidu & 100 & 5 & & & & & & \\
\hline Mõtstare & 40 & 3 & 2 & & 2 & 1 & 3 & \\
\hline Nõmme & 15 & 2 & 4 & 8 & 2 & & & \\
\hline Oosemägi & 120 & 10 & 14 & $6-20$ & $2-4$ & & & 3 \\
\hline Madal & 100 & 4 & 5 & & & 4 & $2-4$ & \\
\hline Kivipalu & 140 & 17 & 5 & $5-20$ & 5 & 8 & $2-5$ & 2 \\
\hline Kindapäka & 80 & 6 & 4 & $5-10$ & $2-3$ & 1 & & 1 \\
\hline Mõsumägi & 70 & 5 & 3 & 5 & 4 & 11 & 4 & 2 \\
\hline Laaritsamägi & 100 & 7 & 6 & $10-25$ & $3-4$ & 1 & 4 & \\
\hline Väike & 140 & 10 & 3 & $15-20$ & $1-3.5$ & 1 & & 3 \\
\hline Taevaskoda & & & & & & & & \\
\hline $\begin{array}{l}\text { Suur } \\
\text { Taevaskoda }\end{array}$ & 150 & 20 & 12 & $20-25$ & $2-6$ & 8 & $2-6$ & 3 \\
\hline
\end{tabular}


more consistent with the general stress field that once formed the joints in the bedrock.

The number of visible joints in the outcrop wall depends largely also on the wall direction with respect to the predominant joint set orientation. So far the collected data do not allow us to give an accurate spacing index of the joint sets.

\section{The character and extent of joints}

Closed unfilled joints are prevailing in the sandstones of the Burtnieki Formation. Joint surfaces are closely pressed together, thus most joints occur in the exposures only as linear surfaces. In very rare cases open joints, $3-5 \mathrm{~cm}$ wide are found. They may, in fact, have been formed by gravitational sliding during the formation of the outcrop wall. Displacements along the joints are almost missing, but if they occur, their existence can be explained by the gravitational sliding movements mentioned above.

The jointing of sandstones is induced by regional stresses which have been repeatedly exerted on our area by large, global-scale tectonic processes. As a result of these events the entire sedimentary bedrock sequence has been broken by joints into smaller or bigger blocks. Due to the compressional stresses that have been prevailing throughout our geological history, both the open fractures and vertical displacements along the joints are rare in our area. Although in similar stress field conditions the horizontal block movements along the joints are to be expected, so far there is no evidence of comprehensive horizontal movements in our bedrock sequence.

It is difficult to estimate the horizontal extent of joints. This can best be done along the outcrop wall if it coincides with the joint direction. The horizontal extent is usually $5-20 \mathrm{~m}$, rarely exceeding $25 \mathrm{~m}$, while the statistical average is 15-20 m ( 25 cases out of 39 measurements). Further away the fracture disappears and a new fracture may appear in some distance.

The vertical extent of joints is mostly $1-3 \mathrm{~m}$ (in 32 cases out of 50 measurements), rarely exceeding $5 \mathrm{~m}$. The vertical termination of joints is evidently induced by more clayey interlayers, which are disturbing the lithological homogeneity of the rock. For that reason the length of the dipping joints is slightly higher - usually $4-5 \mathrm{~m}$ (Table 1 ). Also tilted joints are vertically terminated at the boundaries of lithologically different interbeds.

Most fractures in the studied sandstones of the Burtnieki Formation are vertical or subvertical (in 80 cases out of 119), about $35 \%$ of the joints are tilted (Table 1). The declivity of tilted joints is varying between $30^{\circ}$ and $80^{\circ}$; the statistical maximum remains at $60-70^{\circ}$ (Fig. 2). Although block movements are more likely connected to dipping joints than to vertical ones, clear evidences of rock displacements along tilted joints are missing. The high declivity angle of dipping joints may hamper horizontal movements along them. However, due to the limited research area any final decision would be speculative. 


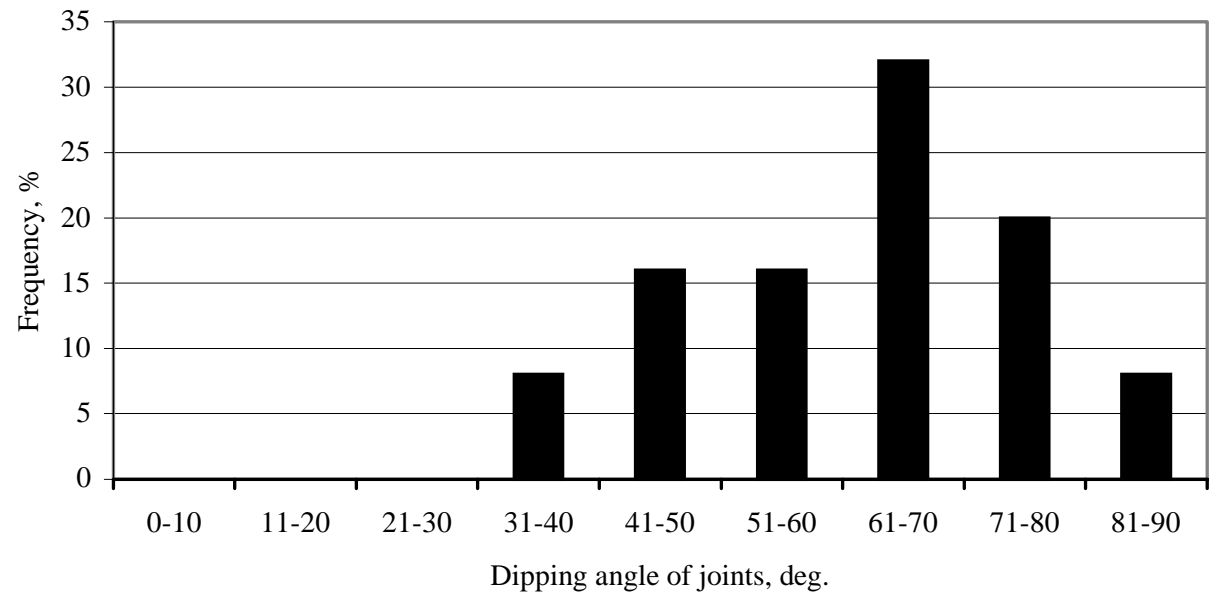

Fig. 2. Histograms of the joint declivity.

A considerable change in joint declivity was observed in three cases in the outcrop walls of Suur Taevaskoda and Mõsumägi. The dipping angles of discrete joints changed in an upward direction from $70^{\circ}$ to $30^{\circ}$ at Mõsumägi and from $50^{\circ}$ to $80^{\circ}$ and from $20^{\circ}$ to $60^{\circ}$ at Suur Taevaskoda. It is difficult to explain the formation of such joints by tectonic stresses. Most likely the declivity change of a tilted joint has a lithogenetic origin or is induced by the pressure movements in the horizontal direction.

Morphologically, the joint surfaces are usually even and planar-plane. Considering the relatively weak cementation degree and complicated bedding character of sandstones, such a surface feature is somewhat unexpected and needs further investigation.

\section{Orientation of joints}

In all, the orientation of 88 joints was measured and a corresponding rose diagram compiled (Fig. 3). The diagram reveals clearly a nearly orthogonally oriented joint system made up of two dominant joint sets with azimuth bearings of strikes $287^{\circ}$ and $006^{\circ}$. Such an orientation practically coincides with the joint directions in the underlying Aruküla Formation measured earlier in the vicinity of Tartu and Kallaste (about 40-70 km north of our study area) but differs markedly from the predominant joint orientations in the sandstones of the Burtnieki Formation all over South Estonia. It is more likely that in the Tartu and Kallaste area the orientation of joints in sandstones is of regional tectonic rather than stratigraphical-lithological origin, as was assumed earlier (Kleesment \& Pirrus 2000). 

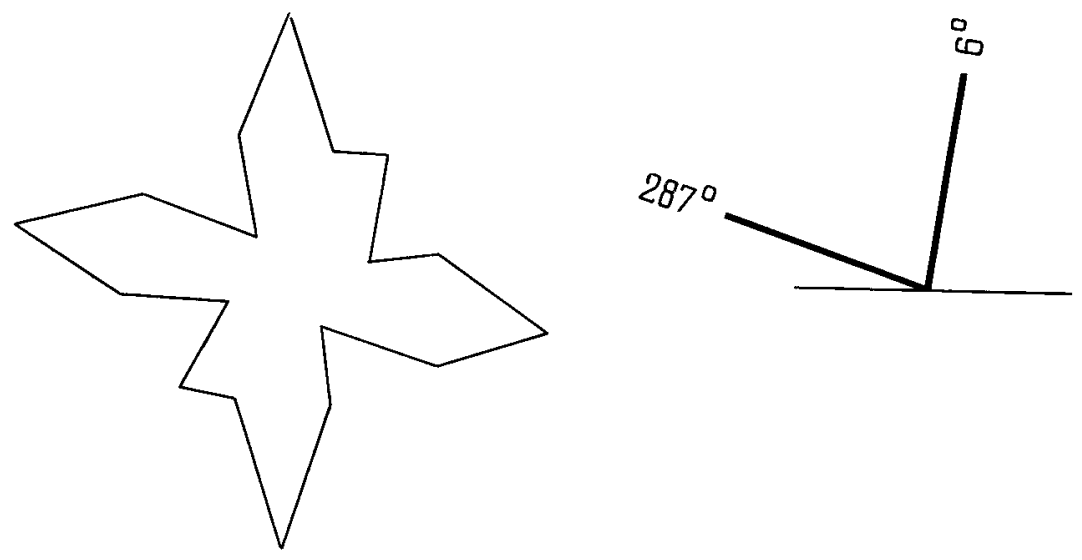

Fig. 3. Rose and vector diagrams of joint orientations in Devonian sandstones of the Ahja River outcrops.

The main joint directions presented in the rose diagram coincide well with the orientation of the linear sections of the river valley (Figs. 1 and 3). This, however, clearly demonstrates that the predominant orientation of erosional channels is in good accordance with the direction of joints. At the same time, the general trend of the valley from NNW to SSE seems to have no direct connection with the jointing of the rock complex. The general orientation of the valley is probably of an exarational origin. Also, the abundance of iron concretions in the pebbles of fluvioglacial origin, which come from the Devonian sandstones just south of our field area (Kleesment et al. 1993), hints to the erosional activity of glaciers and their melt waters. So far the erosion-resistant hydrogoethitic concretions have been found only in the Devonian outcrops located in the middle course of the Ahja River.

Thus, this joint system seems to have played a crucial role mainly in the formation of the local and not regional relief features. This regularity appears only when the statistical mean values of joint orientations are compared with the linear landscape features of the surrounding area. As the number of our measurements was small, this connection was often indistinct. A large number of joint measurements are needed to get statistically reliable values for the dominant directions of joint sets.

\section{Connection of joints with springs and cave structures}

Along the Kiidjärve-Saesaare section a direct connection between the joints, springs, and cave structures in the exposures is obvious. However, due to the inundation of numerous springs and caves by the Saesaare water reservoir, many similar structures remained out of the reach of our investigations and thus, details of their morphology are unclear. In most cases only the uppermost part of 
the cave was visible. Nevertheless, 6 caves and 14 smaller gullies were explored in our study area. The length of the caves is mostly $1-6 \mathrm{~m}$. The openings are isometric or flat, the width generally exceeding the height, which indicates that the running water has considerably enlarged joint dimensions, in particular in the outflow zones of springs. This has finally led to the collapse of the cave roofs, which has entirely distorted the morphology of the primary joint, except for Neitsikoobas cave at the Väike Taevaskoda which is located outside the Saesaare water reservoir. The cave has been formed at the intersection point of vertical and tilted joints. It reaches $14.6 \mathrm{~m}$ in depth and has an upright aperture (Fig. 4). The springs which give rise to the numerous brooks following the fractures are inundated by reservoir waters. They appear only in the caves of Taevaskoda outcrops. Due to flooding, we could not reach the greater part of a cave in the Oosemägi outcrop, one of the biggest caves of the region. Today the cave is only $4 \mathrm{~m}$ deep. The investigations before the inundation by the Saesaare reservoir recorded a $9 \mathrm{~m}$ deep cave from which started a $30 \mathrm{~m}$ long passage into the sand wall.

It has to be mentioned that about $50 \%$ of the caves are related to the dipping joints, or more precisely, they develop at the junctions of dipping and vertical joints (Fig. 4). Similar zones of weakened rocks have been detected also in other regions (Kleesment \& Pirrus 2000). They are the most favourable places for the development of suffosional processes and for the formation of cave structures. As the vertical extent of upright joints in most outcrops is below $3 \mathrm{~m}$, high caves

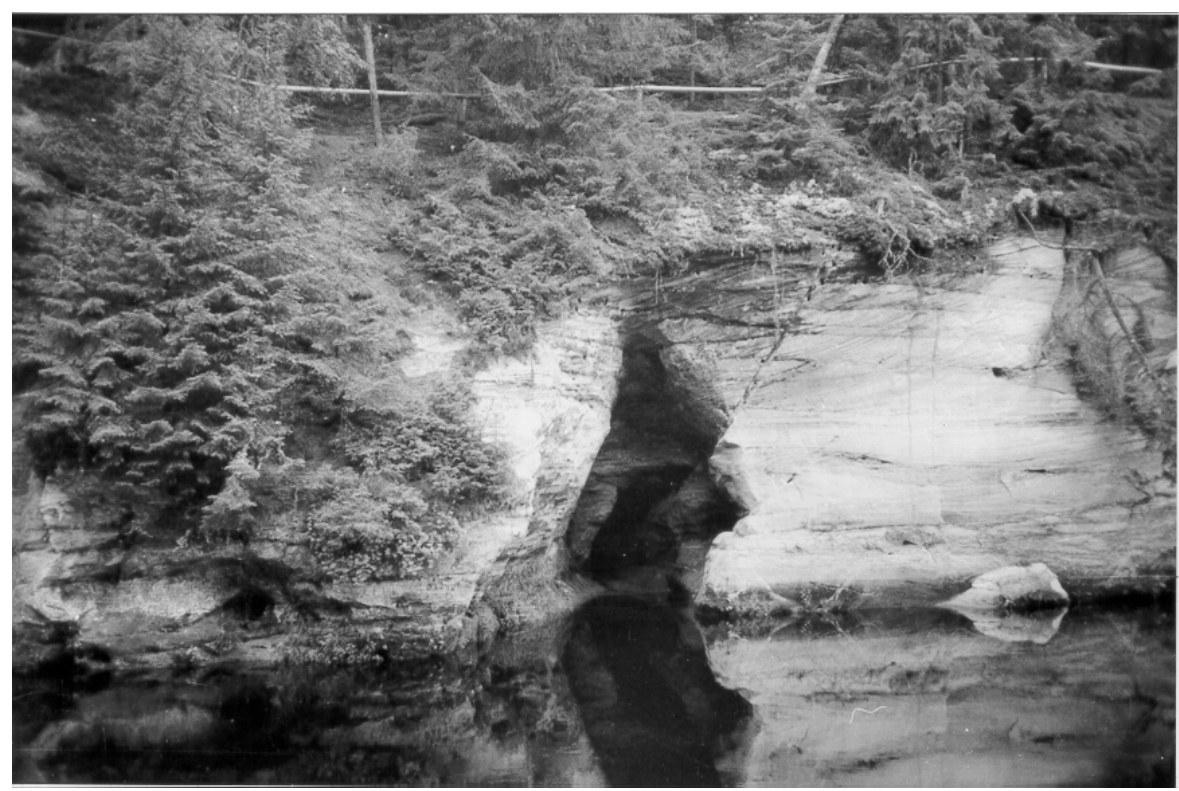

Fig. 4. Upright cave opening of Neitsikoobas cave at Väike Taevaskoda. The opening is located at the junction of joints with different dips. 
are rare in Devonian sandstones. Instead, the running water is continuously enlarging the caves, which finally brings their rooves to a collapse and gives the caves a flat arch-shaped morphology (Figs. 5 and 6).

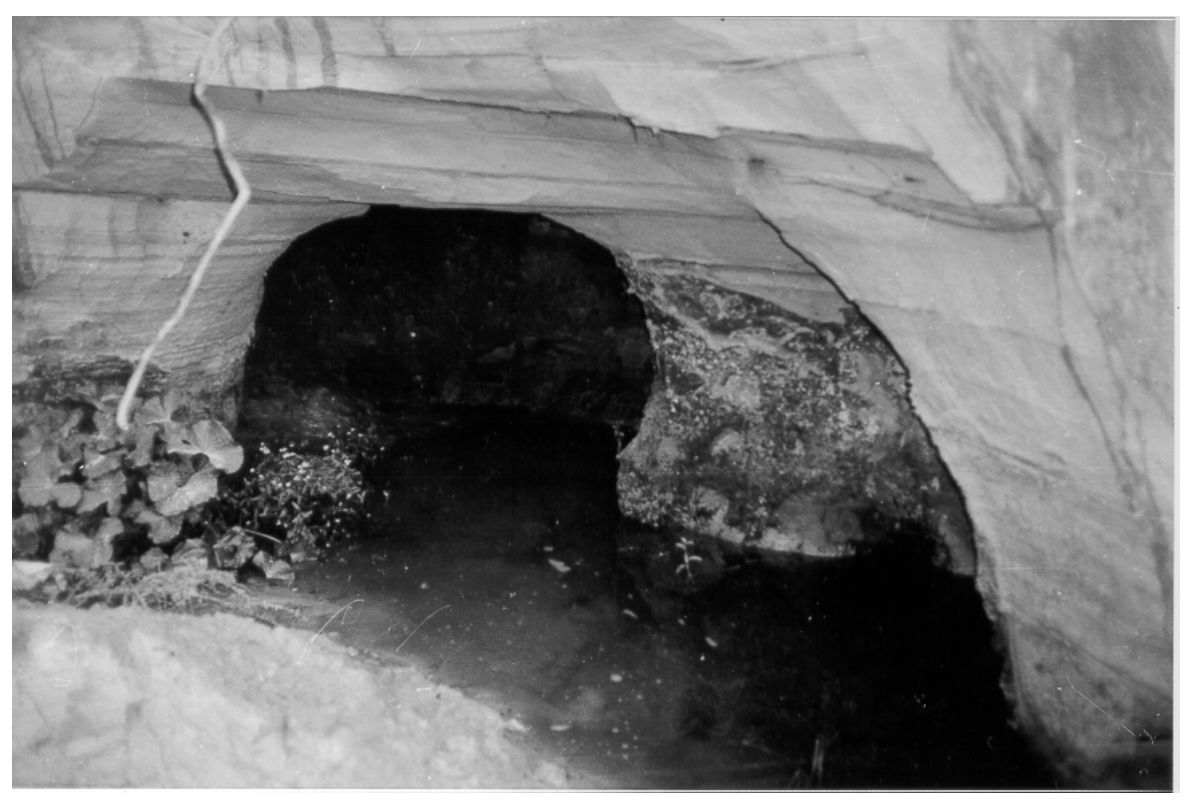

Fig. 5. Visible connection with fractures disappears as the cave widens and a round arch-like bearing is formed.

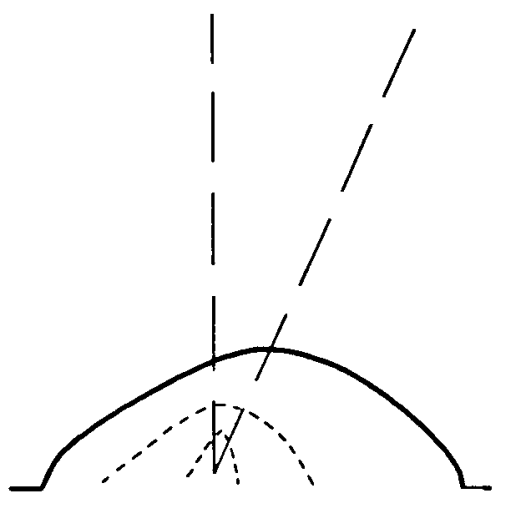

a b

$\mathrm{c}$

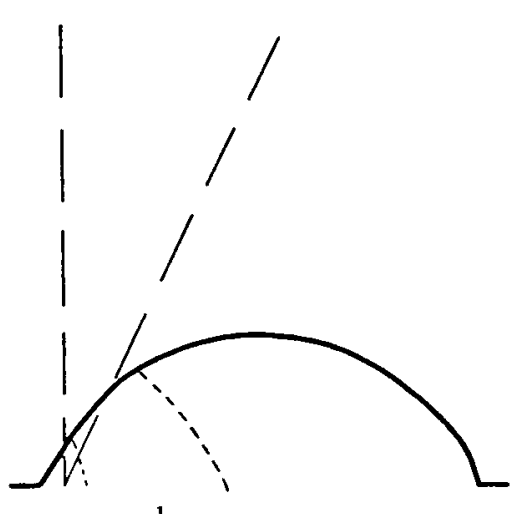

a b

$\mathrm{c}$

Fig. 6. Formation of the cross-section of the cave opening: a, the initial upright triangular shape of the cave opening; $b$, cross-sections of a developing cave passage, located symmetrically (left) and asymmetrically (right) with regard to joints; c, the final shape of the cave which has lost direct connection with joints. Broken lines show the direction of joints. 
In general, a cave or a small gully occurs in every $70-80 \mathrm{~m}$, which marks active spring outflow into the river valley. Comparison of this density with the average spacing of joints shows that only every fifth joint is liable to go through the suffosion process and become an outlet for an intense flow of water and sand.

\section{CONCLUSIONS}

Based on our investigations, the following conclusions can be drawn.

1. The horizontal extent of joints surpasses their vertical extent almost by ten times (15-20 m and 1.5-3 m, respectively). This is due to the vertical heterogeneity of sandstone, caused by the bedding.

2. Vertical joints are predominant (65\%), the declivity of dipping joints is mostly in the limits of $60-70^{\circ}$. Dipping and closed fractures suggest that horizontal compressional stresses were dominating during the formation of joints in Devonian sandstones.

3. The prevailing joint system in the Burtnieki Formation is made up of two crossing joint sets with the azimuth bearings of strikes $287^{\circ}$ and $006^{\circ}$. These values fit well with the orientation of the main joint sets in the underlying Aruküla Formation, observed near the towns of Tartu and Kallaste (Kleesment \& Pirrus 2000). Thus, the joint systems in the Devonian sandstone complex in this region is most probably of regional tectonic origin.

4. The average spacing of joints of approximately $15-20 \mathrm{~m}$ is a prerequisite for groundwater circulation along the blocks of rocks, especially near the valley slopes, where joints may open due to gravitational forces. The outflow channels and caves are formed at the junctions of vertical and dipping joints, where the monolithic structure of rocks has been weakened.

The conclusions and data obtained can be used as a basis for further studies of joints in the Devonian sandstone in other regions of Estonia. Comparison of the data from different regions will give an opportunity to understand the formation history of sandstone jointing.

\section{ACKNOWLEDGEMENTS}

We appreciate very much the valuable suggestions by I. Tuuling and M. Bjerceus. We are also grateful to R. Vaher for his critical comments, K. Ronk for preparing the drawings, and $\mathrm{H}$. Pohl for linguistic improvements. The study was financed by the research projects No. 0140226 and No. $0332088 \mathrm{~s} 02$ of the Ministry of Education of Estonia. 


\section{REFERENCES}

Heinsalu, Ü. 1987. Eesti NSV koopad. Valgus, Tallinn.

Heinsalu, Ü., Pirrus, E. \& Tiirmaa, R. 1992. Kas lõhe raba all? Eesti Loodus, 12, 622-629.

Kleesment, A. \& Mark-Kurik, E. 1997. Devonian. Introduction. Middle Devonian. In Geology and Mineral Resources of Estonia (Raukas, A. \& Teedumäe, A., eds.), pp. 107 and 112-121. Estonian Acad. Publ., Tallinn.

Kleesment, A. \& Pirrus, E. 2000. Fracture systems in Devonian sandstones, South Estonia. Proc. Estonian Acad. Sci. Geol., 49, 284-293.

Kleesment, A.-L., Pirrus, E. \& Puustusmaa, R. 1993. Occurrence of Devonian concretions as pebbles in Quaternary sediments. Proc. Estonian Acad. Sci. Geol., 42, 8-14.

Miidel, A. 1966. On the connection of the directions of the Estonian valleys with the directions of tectonic joints. In Eesti Geograafia Seltsi aastaraamat 1964/1965, pp. 18-33. Valgus, Tallinn (in Russian).

Miidel, A. 1982. On the interdependence between the fracturing of the Devonian rocks and the direction of the middle cource of the Võhandu River valley (South Estonia). Eesti NSV TA Toim. Geol., 31, 80 (in Russian).

\section{Devoni liivakivide lõhelisus Kiidjärve-Taevaskoja piirkonnas}

\section{Enn Pirrus, Anne Kleesment ja Margus Sööt}

On esitatud andmed Ahja jõel Kiidjärvest kuni Taevaskoja paljanditeni paiknevate Devoni liivakivipaljandite lõhelisuse kohta. Lõhed on horisontaalsuunas jälgitavad enamasti 15-20 m ulatuses, kuna nende vertikaalulatus on liivakompleksi kihilisusest sõltuvalt tunduvalt väiksem - 1,5-3 m. Püstlõhede kõrval on rohkesti kaldlõhesid (35\%) valdava kaldenurgaga $60-70^{\circ}$. Lõhed on suuremas osas suletud ja moodustavad kaks selgemat lõhestikku rõhtsihtidega $287^{\circ}$ ja $6^{\circ}$. Lõhede jaotus horisontaalsuunas on ebaühtlane, kuid arvutuslik keskmine vahekaugus on neil 15-20 m. Kaldlõhede ja püstlõhede ristumiskohad on sufosiooniliste koopastruktuuride kujunemisel eelisseisundis. Lõhede piiratud vertikaalulatuse tõttu on enamik koopaid madala kaarja ristläbilõikega, mis on tingitud voolukanali laienemisest lõhe allosas peamiselt külgsuundades ja selle põhjustatud laevaringutest ning võlvja kandestruktuuri kujunemisest.

Süstemaatiline uuring lõhede kohta Kiidjärve-Taevaskoja polügoonil annab usaldusväärsed tugiandmed samasisuliste uuringute jätkamiseks Eesti teistes piirkondades. 


\title{
Трещиноватость девонских песчаников на испытательном полигоне Кийдъярве-Таеваскоя, Юго-Восточная Эстония
}

\begin{abstract}
Энн Пиррус, Анне Клеесмент и Маргус Сеэт
Представлены данные о трещиноватости среднедевонских песчаников в зоне обнажений по р. Ахья, на отрезке длиной 6 км от Кийдъярве до Таеваскоя. В горизонтальном направлении протяженность трещин охватывает более 15-20 м, в вертикальном же не превышает 1,5-3 м. Вертикальное распространение трещин часто ограничивается наличием в разрезе тонких прослоев более глинистых пород, гасящих напряжения трещинообразования. Преобладают вертикальные трещины, но немало наклонных - около $35 \%$. Угол наклона относительно горизонтали, как правило, в пределах $60-70^{\circ}$. Трещины в большинстве случаев закрыты и ориентированы в пространстве двумя отчетливыми системами $-287^{\circ}$ и $6^{\circ}$. Места пересечения наклонных и вертикальных трещин наиболее подходящи для выхода подземных вод и для образования здесь пещерообразных пустот. Интервал между трещинами в разрезе составляет в среднем 15-20 м.

Полученные результаты испытаний на трещиноватость коренных пород с повышенной обнаженностью закладывают надежную базу опорных данных для проведения аналогичных работ в других регионах Эстонии.
\end{abstract}

